\title{
Faunistic composition of hymenopteran parasitoids in cultivation of Eucalyptus urophylla S.T. blake and adjacent areas of Seasonal Semi-deciduous Montana forest situated in the Semi-arid State of Bahia, Brazil
}

\author{
Rita de Cássia Antunes Lima de Paula ${ }^{\circledR \oplus}$, Jennifer Guimarães Silva ${ }^{1 \oplus}$, \\ Daniell Rodrigo Rodrigues Fernandes ${ }^{2}$, Aldenise Alves Moreira ${ }^{1}{ }^{\odot}$, Onice Teresinha Dall'Oglio ${ }^{3 \odot}$, \\ Juvenal Cordeiro Silva Junior ${ }^{1 \oplus}$ \& Raquel Pérez-Maluf ${ }^{1 \odot}$
}

1. Universidade Estadual do Sudoeste da Bahia, Vitória da Conquista, BA, Brazil. 2. Instituto Nacional de Pesquisas da Amazônia, Manaus, AM, Brazil. 3. Universidade Federal de Mato Grosso (UFMT), Cuiabá, MT, Brazil.

\section{EntomoBrasilis 15: e965 (2022)}

\begin{abstract}
Hymenopteran parasitoids are insects that play a fundamental role in ecosystems as they reduce the population density of insects that are considered pests in monocultures. However, little is known about the fauna in association to the eucalyptus trees in comparison to adjacent native vegetations. Therefore, this study was aimed to determine the fauna of parasitoid wasps that occur in a commercial plantation of Eucalyptus urophylla S.T. Blake, as well as in native forest and capoeira environments in the plateau of Conquista, Bahia, a semiarid region of Bahia. The study was conducted for two consecutive years with monthly monitoring using five Malaise traps. The collected insects were sorted and identified at the family level. The faunal indices referring to the families of each area were studied by evaluating the frequency, species richness, shannon diversity and equitability. In total, 5,899 individuals were collected, which were distributed in 24 families and eight superfamilies. The most abundant families were Braconidae, Ichneumonidae and Bethylidae. Capoeira and eucalyptus trees showed greater similarity and equitability when compared to the rest of the forest. Given the diversity of Hymenopteran parasitoid families found in the area, it was concluded that the maintenance of native vegetation environments is important, even at the initial stage of succession.
\end{abstract}

Keywords: Braconidae; capoeira; diversity; Malaise; native forest.

\section{Edited by:}

Alberto Moreira Silva-Neto

Article History:

Received: 31.viii.2021

First Answer: 01.x.2021

Accepted: 23.xii.2021

Published: $01 . i i .2022$

Corresponding author:

Rita de Cássia Antunes Lima de Paula ७rcassia@uesb.edu.br

Funding agencies:

¿ Fundação de Amparo à Pesquisa do Estado da Bahia

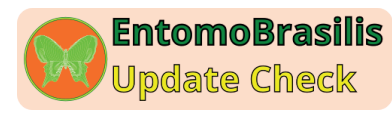

doi: 10.12741/ebrasilis.v15.e965

(c) The Author(s) 2022. Published by Entomologistas do Brasil

This article is published by Entomologistas do Brasil and licensed under Creative Commons Licence 4.0 (CC-BY)

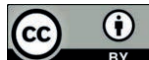

¿ Article Full Open Access
Among the eucalyptus species present in Brazil, Eucalyptus urophylla S. T. Blake (Myrtaceae) is one of the most cultivated species, which has a good productivity due to its high growth rate. In addition, it has a huge potential to be used as a forest frontier in the reforestation areas, mainly in the Northern and Northeastern regions, where this is a growing practice (SCANAVACA-JUNIOR \& GARCIA 2004).

The state of Bahia is a large eucalyptus producer with extensive areas of monoculture, which is always vulnerable to phytosanitary problems, such as pest-insects, which restrict production, causing damage to national eucalyptus plantations. Severe attacks on this crop can be caused by leaf-cutting ant species (DelLa Lucia et al. 1993), defoliating lepidopterans (ZANuncio et al. 1993), galler wasps (WILCKEn \& BertI FILHo 2008), weevils (SouzA et al. 2016) and wasps (Masson et al. 2017).

Native vegetation close to the eucalyptus plantation areas can reduce pest-insect populations of the crop in question, as the environment with greater plant diversity tends to provide greater richness and abundance of beneficial insects (SILVA \& BRITO 2015). It is even recommended as a pest management strategy for this crop (DALLO'GLIO et al. 2003).

Among natural enemies, those with parasitoid behavior, play a fundamental role in ecosystems as they are able to reduce the population density of other arthropods (mainly insects that are considered pests), and consequently, their decline (HEINRICHS \& BARRION 2004; Perioto et al. 2004; Fernandes et al. 2018; Barbosa et al. 2019).

There are several studies comparing the diversity of parasitoid hymenopterans associated with monocultures, with adjacent areas of native vegetation (FreItAs et al. 2002; DALL'OGLIO et al. 2003; Oliveira et al. 2014; Schoeninger et al. 2019), the main families sampled being, Ichneumonidae, Braconidae (DAlL'Oglio et al. 2003), Ichneumonidae (LARA et al. 2015) and Encyrtidae (LARA et al. 2015; SCHOENINGer et al. 2019).

Faunistic studies involving study of the diversity of parasitoid wasps in monoculture environments and surrounding vegetation are extremely important as they help to understand the community of these existing insects, as well as to understand the potential of each group, providing basic and important information for future bioecological studies of the species. This would aid in the monitoring and development of pest management 
programs, and study of natural enemies (GARLET et al. 2016).

The state of Bahia is constituted by the forest formations of Caatinga, Cerrado and Atlantic Forest types (IBGE 2012). The semiarid region of this state has a territorial area of 446,221 km² and 278 municipalities (CONDEL SUDENE 2017). Among the physiognomies that constitute the region, we can mention the Seasonal Semideciduous Montana Forest, regionally called "Vine Forest" (SANTOS Neto et al. 2015). This type of vegetation is predominantly composed of mediumsized trees with a loss of up to $50 \%$ of the leaves during the dry period, surrounded by woody vines that remain green throughout the year.

The knowledge about the hymenopteran parasitoid fauna of the semiarid region of the state of Bahia presents studies related practically to relevant agricultural crops in this region, such as coffee plantations (Melo et al. 2007; PALMASantos \& Pérez-Maluf 2010). In the different types of natural vegetation that have been introduced in this region, similar studies are still less. In the fragments of Caatinga, the studies of FERNANDEs et al. (2019a) in the municipality of Jequié and SiLva et al. (2019) in Senhor do Bonfim can be mentioned, and the study by Santos \& Pérez-Maluf (2012) can be mentioned in the areas of Seasonal Semideciduous Montana Forest and coffee plantations in Vitória da Conquista.

Given the lack of information about this group of insects, this study aims to conduct a survey of the diversity of hymenopteran parasitoids that occur in a plantation of Eucalyptus urophylla S.T. Blake, as well as in the surrounding environments constituted by Seasonal Semi-deciduous Montana Forest (Capoeira and native Forest) in a semiarid region of Bahia.

The sampling was carried out in three different phytophysiognomies - E. urophylla, Capoeira and native forest culture in the municipality of Barra do Choça, Bahia, Brazil, at an altitude of $847 \mathrm{~m}$ above sea level and characterized by Aw type tropical climate according to the Köopen classification (SEI 2021).

Monthly collections were carried out from January 2016 to December 2017, using five Malaise traps, which were installed at the following coordinates: Point $1-14^{\circ} 52^{\prime} 33.59^{\prime} \mathrm{S}$ and $40^{\circ} 41^{\prime} 45.25^{\prime} \mathrm{W}$ and Point $2-14^{\circ} 52^{\prime} 35.99^{\prime} \mathrm{S}$ and $40^{\circ}$ $41^{\prime} 43.03 \mathrm{~W}$ (located at $200 \mathrm{~m}$ and $300 \mathrm{~m}$ from the edges of the eucalyptus plantation, respectively); Point 3 - 14 ${ }^{\circ} 52^{\prime} 45.99^{\prime} \mathrm{S}$ and $40^{\circ} 41^{\prime} 40.3403 \mathrm{~W}$ (located at $250 \mathrm{~m}$ from the edge of the capoeira); Point 4 - 14 $52^{\prime} 57.16^{\prime \prime} \mathrm{S}$ and 40 $4^{\prime} 37.78^{\prime \prime} \mathrm{W}$ and Point 5 - 14 $4^{\circ} 52^{\prime} 55.3^{\prime \prime} \mathrm{S}$ and $40^{\circ} 41^{\prime} 36.00^{\prime \prime} \mathrm{W}$ (located at $200 \mathrm{~m}$ and $300 \mathrm{~m}$ from the edges of the native forest respectively). The phytophysiognomies are not separate rather contiguous.

The plantation of E. urophylla has an area of 30 ha and is more than 10 years old, with the trees arranged with a spacing of $3 \times 3 \mathrm{~m}$. The capoeira has an area of about $6 \mathrm{ha}$, in the initial stage of succession, consisting of pioneer species reaching heights of up to $5 \mathrm{~m}$, such as Pyrostegia venusta (Ker Gawl.) Miers, Vernonia chamaedrys Less., Zanthoxylum rhoifolium Lam and Solanum lycocarpum St. Vall. The native forest has an area of approximately 86 ha, being classified as Seasonal Semideciduous Montana Forest with the presence of some species, which are around 15 meters tall, such as Anadenanthera colubrina (Vell.) Brenan, Trichilia hirta Le and Aspidosperma pyrifolium Mart.

The screening of hymenopteran parasitoids including Chrysidoidea was carried out at the Laboratory of SemiArid Biodiversity (LABISA) at the Universidade Estadual do Sudoeste da Bahia (UESB), and subsequently quantified and identified at the family taxonomic level. For each superfamily, the following literature were used: HANSON \& GAULD (2006) (Ceraphronoidea, Evanioidea, Ichneumonoidea, Platygastroidea, Proctotrupoidea, Stephanoidea and Trigonalyoidea), RonquisT (1995) (Cynipoidea) and GRISSEL \& Schauff (1997) (Chalcidoidea). In this study, it was decided not to consider Scelionidae synonymous with Platygastridae, according to Ortega-Blanco et al. (2014) and Talamas et al. (2015). Afterwards, the classification of Proctotrupoiidea/ Diaprioidea by AgUIAR et al. (2013) was updated.

Part of the identified species were incorporated into the Brazilian Entomological Collections under the care of the following curators: Valmir A. Costa (Collection of Entomophagous Insects "Oscar Monte", at Instituto Biológico, Campinas), Angélica M. Penteado-Dias (Entomological Collection of the Department of Ecology and Evolutionary Biology, Universidade Federal de São Carlos - DCBU) and Marcelo T. Tavares (Entomological Collection of the Universidade Federal do Espírito Santo- UFES). Some voucher specimens remained at the collection of LABISA (Laboratory of Semi-Arid Biodiversity), at UESB, campus of Vitória de Conquista, BA, under the care of Raquel Pérez-Maluf.

The faunal indices adopted in this study were frequency, species richness, shannon diversity and equitability. The data were analyzed using the statistical program Past, version 2.16 (HAMmer et al. 2001) with a confidence interval (CI) of 95\%.

The comparison of the diversity of the families captured in each physiognomy was performed using rarefaction curves by the bootstrap process with resampling in order to obtain a confidence interval for the family richness. Bootstrap analyses were calculated using EstimateS Win9.1 software (COLWELL 2013), using 2000 randomizations and 95\% confidence interval.

A total of 5,988 Hymenopteran parasitoid specimens were collected in the three phytophysiognomies, belonging to eight superfamilies and distributed in 24 families (Table 1). In Brazil, there are 15 superfamilies and 42 families (OLIVEIRA et al. 2021) and, according to the data in this study, it is possible to verify the presence of $53 \%$ and $57 \%$ of these values, respectively, which indicates that the sampled area has a high representation of parasitoid hymenopterans.

The phytophysiognomy that presented the highest abundance of individuals collected by trap was the capoeira with 1,814 insects/trap, followed by the native forest, with 1,373.5 insects/trap, and eucalyptus, with 713.5 insects/trap, which means that both capoeira and forest had an important participation in the collection of hymenopteran parasitoids when compared to monoculture. This bias may be related to the fact that these phytophysiognomies (capoeira and native forest) have a higher degree of complexity, which creates more nesting sites, shelter and greater availability of food resources (pollen, nectar and honeydews) for adults (GoDFRAY 1994), contributing to ecosystem services (Salas et al. 2019; SILVA et al. 2019; O'DONNELL \& WRIGH 2021) when compared to monoculture.

Similar results were found by DALL'OgLIO et al. (2003) who also found a higher amount of Hymenopteran parasitoid/ trap in the border environment rather than in the eucalyptus monoculture. In Goiás, Marchiori \& PenteAdo-Dias (2002) also observed more Hymenopteran parasitoids in Capoeira than in the forest. More open areas such as borders and even Capoeira can act as transition areas for these insects, contributing to the movement and distribution of parasitoids to the interior of the cultivation.

The most abundant superfamily was Ichneumonoidea (48.03\%) followed by Chalcidoidea (19.82\%), which together 
Table 1. Richness and abundance of Hymenopteran parasitoid families collected in Eucalyptus urophylla (E), Capoeira (C) and Native Forest (M) in the plateau of Conquista, Bahia, Brazil, from January 2016 to December 2017.

\begin{tabular}{|c|c|c|c|c|c|}
\hline \multirow{2}{*}{$\begin{array}{l}\text { SUPERFAMILY } \\
\text { Family }\end{array}$} & \multicolumn{3}{|c|}{ Abundance } & \multirow{2}{*}{ Grand Total } & \multirow{2}{*}{$\operatorname{RF}(\%)$} \\
\hline & E & c & M & & \\
\hline CERAPHONOIDEA & 147 & 6 & 11 & 164 & 2.74 \\
\hline Ceraphronidae & 147 & 6 & 11 & 164 & 2.74 \\
\hline CHALCIDOIDEA & 272 & 543 & 372 & 1187 & $1 ., 82$ \\
\hline Aphelinidae & 5 & 2 & 3 & 10 & 0.17 \\
\hline Chalcididae & 22 & 113 & 47 & 182 & 3.04 \\
\hline Encyrtidae & 13 & 7 & 22 & 42 & 0.70 \\
\hline Eucharitidae & 1 & 56 & 1 & 58 & 0.97 \\
\hline Eulophidae & 70 & 74 & 86 & 230 & 3.84 \\
\hline Eupelmidae & 2 & 18 & 22 & 42 & 0.70 \\
\hline Eurytomidae & 9 & 65 & 8 & 82 & 1.37 \\
\hline Mymaridae & 88 & 32 & 82 & 202 & 3.37 \\
\hline Perilampidae & 1 & 26 & 2 & 29 & 0.48 \\
\hline Pteromalidae & 48 & 144 & 91 & 283 & 4.73 \\
\hline Signophoridae & 13 & 2 & 0 & 15 & 0.25 \\
\hline Torymidae & 0 & 4 & 8 & 12 & 0.20 \\
\hline CHRYSIDOIDEA & 196 & 302 & 288 & 786 & 13.13 \\
\hline Bethylidae & 186 & 271 & 193 & 650 & 10.86 \\
\hline Chrysididae & 5 & 16 & 12 & 33 & 0.55 \\
\hline Dryinidae & 5 & 15 & 83 & 103 & 1.72 \\
\hline CYNIPOIDEA & 88 & 73 & 54 & 215 & 3.59 \\
\hline Figitidae & 88 & 73 & 54 & 215 & 3.59 \\
\hline EVANIOIDEA & 44 & 69 & 44 & 157 & 2.62 \\
\hline Evaniidae & 44 & 69 & 44 & 157 & 2.62 \\
\hline ICHNEUMONOIDEA & 469 & 691 & 1716 & 2876 & 48.03 \\
\hline Braconidae & 306 & 430 & 817 & 1553 & 25.94 \\
\hline Ichneumonidae & 163 & 261 & 899 & 1323 & 22.09 \\
\hline PLATYGASTROIDEA & 92 & 55 & 84 & 231 & 3.86 \\
\hline Platygastridae & 86 & 31 & 71 & 188 & 3.14 \\
\hline Scelionidae & 6 & 24 & 13 & 43 & 0.72 \\
\hline DIAPRIOIDEA & 119 & 75 & 178 & 372 & 6.21 \\
\hline Diapriidae & 108 & 31 & 101 & 240 & 4.01 \\
\hline Monomachidae & 11 & 44 & 77 & 132 & 2.20 \\
\hline Grand Total & 1427 & 1814 & 2747 & 5988 & 100.00 \\
\hline No. of ins./trap & 713.5 & 1814 & 1373.5 & 1197.6 & \\
\hline $\mathbf{S}$ & 23 & 24 & 23 & 24 & \\
\hline
\end{tabular}

Note: Number of Malaise traps in eucalyptus and in the forest: two traps; Number of Malaise traps in capoeira: one trap. Source: elaborated by the author. Where: no. of ins./trap: number of insects per trap; RF: Relative Frequency; S: Family Richness.

comprise of almost $70 \%$ of the collected parasitoids (Table 1). Possibly, the predominance of Ichneumonoidea is due to the fact that it consists of the two most dominant families among all existing groups of Hymenopteran parasitoids (Ichneumonidae and Braconidae) and, therefore, it presents a high number of individuals and high species richness (QUICKE 2015).

Chalcidoidea was also observed to be the richest with 12 families (Table 1) and according to Grissel \& Schauff (1997), this superfamily comprises of 17 families, which shows that the present study represented $70 \%$ of the group. The species of these two superfamilies were the principal participants in biological control programs of agrosystems, such as the use of Cotesia flavipes (Cameron, 1891) (Hymenoptera: Braconidae) in the control of the sugarcane borer Diatraea saccharalis (Fabricius, 1794) (Lepidoptera: Crambidae), among others (Parra \& Coelho Júnior 2019).

Regarding the family richness, among the total of 24 registered families, all were present in capoeira, and, only one of them were absent in the eucalyptus and in the native forest. Signiphoridae was not collected in the forest, and Torymidae was absent from the eucalyptus.

The predominant families in this study were Braconidae (25.94\%), Ichneumonidae (22.09\%) and Bethylidae (10.86\%), which together represented more than half of the collected parasitoids. DALL'Oglio et al. (2003) also observed Braconidae and Ichneumonidae as predominant, with an inverted position with $22 \%$ and $27 \%$, respectively. These families have various parasitism strategies, and hence they are considered as dominant groups in the regulation of herbivorous species (FERnÁndez \& SHARKEY 2006), being surpassed only by the Chalcidoidea (NOYEs 2021).

In capoeira and eucalyptus, the most abundant family was Braconidae, and in the forest, it was Ichneumonidae (Table 1). Both families feed especially on Lepidoptera and Coleoptera larvae and pupae(QUICKE 2015), being of the orders of pests that 
include species of great economic importance in eucalyptus culture. The parasitoids of Apanteles sp. (Braconidae); Apechtis sarsinae and Pimpla videonis (Ichneumonidae) were found in eggs, caterpillars and pupae of Sarsina violascens (HerrichSchaeffer, 1856) (Lepidoptera: Lymantriidae), a primary pest of eucalyptus plantations, mainly in Bahia (SILVA 1964). In the plantations of E. urophylla ZaNUNCIO et al. (2009) found a high rate of parasitism caused by Itoplectis sp. (Ichneumonidae) in pupae of Euselasia eucerus (Hewitson, 1872) (Riodinidae), another eucalyptus defoliating pest species. Considering the biological potential that these families have and as they act as agents for the biological control of relevant pest-species in that culture, they deserve attention in terms of identification at a species level.

Regarding the Shannon diversity index of the Hymenopteran parasitoid families for each phytophysiognomy, the capoeira had the highest index $\left(H^{\prime}=2.50\right)$, followed by the eucalyptus plantation $\left(H^{\prime}=2.47\right)$ and the native forest $\left(H^{\prime}=2.07\right)$. The highest indices (capoeira and eucalyptus) did not differ from each other by the $t$ test with $5 \%$ probability level $(t:-0.825 p>0.05)$. The forest showed a significant difference as compared to the capoeira ( $\left.t: 12.761 \mathrm{p:} 1.2043^{\mathrm{E}-36}\right)$ and the eucalyptus ( $t: 12.143$ $\left.p: 2.516^{\mathrm{E}-33}\right)$.
According to the rarefaction curves, it was verified that in capoeira there was a tendency to reach the asymptote curve faster than the other environments (even with only one Malaise trap installed in this environment). In addition, it presented greater family diversity and a higher number of sampled insects than eucalyptus. On the other hand, the native forest, despite having captured a lower number of families, had a greater overall number of captured insects (Figure 1).

Although the environments have captured similar diversity of families, the number of insects in Eucalyptus was lower than the other environments, which may indicate a possible disadvantage for the maintenance of this fauna in this environment. Similar results were found by Fernandes et al. 2019b, who found a lower number of specimens of Ichneumonidae captured with Malaise traps in agricultural areas as compared to the native forests and adjacent pastures, in Rocha province, Uruguay.

Therefore, further detailed studies in similar areas are essential for a better understanding of the parasitoid fauna dynamics in the studied environments (Eucalyptus plantation/ Capoeira/Forest).

\section{5}

0000000000000.000

15

5

0

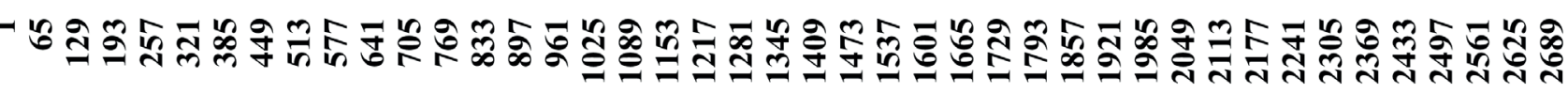
-. Capoeira $\cdots$ Eucalyptus $\cdots$ Native Forest

Figure 1. Parasitoid family diversity by Individuals

\section{ACKNOWLEDGEMENTS}

We are thankful to the Research Support Fundação de Amparo à Pesquisa do Estado da Bahia a (FAPESB) for the scholarship granted to the first author.

\section{REFERENCES}

Aguiar, AP, AR Deans, MS Engel, M Forshage, JT Huber, JT Jennings, NF Johnson, AS Lelej, JT Longino, V Lohrmann, I Mikó, M Ohl, C Rasmussen, A Taeger \& D SKYu, 2013.
Order Hymenoptera. Zootaxa, 3703: 051-062. DOI: https://doi.org/10.11646/zootaxa.3703.1.12

Barbosa, LR, JM Campos, CF Wilcken \& JC Zanuncio, 2019. Forests, pp. 305-317. In: Souza B, L Vázquez \& $\mathrm{R}$ Marucci (Eds.). Natural Enemies of Insect Pests in Neotropical Agroecosystems. Springer, Cham. DOI: https://doi.org/10.1007/978-3-030-24733-1_25

Colwell, R, 2013. Estimate S: Statistical estimation of species richness and shared species from samples. Version 9.1. User's Guide and application. Available in: 
<http://purl.oclc.org/estimates>. [Access: 18.x.2021].

CONDEL SUDENE, 2017. Resolução n 107/2017. Serviço Público Federal Ministério da Integração Nacional Superintendência do Desenvolvimento do Nordeste Conselho Deliberativo. Available in: <http://pesquisa. in.gov.br/imprensa/jsp/visualiza/index.jsp?jornal=1 \&data $=13 / 09 / 2017$ \&pagina $=48>$.

Dall'Oglio, O, TJC Zanuncio, FA Freitas \& R Pinto, 2003. Himenópteros parasitoides coletados em povoamento de Eucalyptus grandis e mata nativa em Ipaba, estado de Minas Gerais. Ciência Florestal, 13: 123-129. DOI : https://doi.org/10.5902/198050981730

Della Lucia, TMC, HG Fowler \& DDO Moreira, 1993. Espécies de formigas cortadeiras no Brasil, pp. 26-31. In: TMC Della Lucia (Eds.). As formigas cortadeiras. Viçosa: Sociedade de Investigações Florestais.

Fernandes, DRR, DG Pádua, RIR Lara, NW Perioto, JP Burla \& E Castiglioni, 2019b. Subfamily composition of Ichneumonidae (Hymenoptera: Ichneumonoidea) from eastern Uruguay. Entomological Communications, 1: ec01016. DOI: https://doi.org/10.37486/2675-1305. ec01016

Fernandes, DRR, JJM Santos, RIR Lara, JC Silva Junior, HA Ferreira \& NW Perioto, 2019a. Fauna de Ichneumonidae (Hymenoptera: Ichneumonoidea) em áreas de Caatinga do Sudoeste da Bahia, Brasil. EntomoBrasilis, 12: 126-131. DOI: https://doi.org/10.12741/ebrasilis.v12i3.837

Fernandes, DRR, RB Querino \& N Hamada, 2018. Order Hymenoptera, pp 339-347. In: JH Thorp \& DC Rogers (Eds.). Thorp and Covich's freshwater invertebrates. Academic Press, Cambridge.

Fernández, F \& MJ Sharkey (Eds). 2006. Introducción a los Hymenoptera de la Región Neotropical. Bogotá: Sociedad Colombiana de Entomologia Y Universidad Nacional de Colombia

Freitas, FA, TV Zanuncio, JC Zanuncio, MAL Bragança \& JMM Pereira, 2002. Similaridade e abundância de Hymenoptera inimigos naturais em plantio de eucalipto e em área de vegetação nativa. Floresta e Ambiente. 9: 145-152. Available in: <https://www.floram.org/article/588e21ffe71 Oab87018b45e6>. [Access: 05.xii.2021].

Garlet, J; E Corrêa-Costa \& J Boscardin, 2016. Levantamento da entomofauna em plantios de Eucalyptus spp. por meio de armadilha luminosa em São Francisco de Assis - RS. Ciência Florestal, 26: 365-374. DOI: https://doi.org/10.5902/1980509822737

Godfray, HCJ, 1994. Parasitoids: Behavioral and Evolutionary Ecology. Princeton University Press Books, Princeton

Grissel, EE \& ME Schauff, 1997. Chalcidoidea. pp. 45-116. In.: Gibson GAP, JT Huber \& JB Woolley (Eds.). Annotated keys to the genera of Neartic Chalcidoidea (Hymenoptera). Ottawa: NRC Research Press

Hammer, $\varnothing$, D A Harper \& PD Ryan, 2001. PAST: Paleontological statistics software package for education and data analysis. Palaeontologia electronica, 4:1, 1-9

Hanson, PE \& ID Gauld, 2006. Hymenoptera de la Region Neotropical. Memoirs of the American Entomological Institute

Heinrichs, EA \& AT Barrion, 2004. Rice-Feeding Insects and Selected Natural Enemies in West Africa: biology, ecology, identification. Manila: International Rice Research Institute

IBGE - Instituto Brasileiro de Geografia e Estatística, 2012. Manuais Técnicos em Geociências. Manual Técnico da Vegetação Brasileira. $2^{a}$ edição revisada e ampliada. Brasil.

Lara, RIR, DRR Fernandes, DR Versuti, MFA Tango \& NW Perioto, 2015. Sampling and diversity of Hymenoptera (Insecta) in an orange orchard/Brazilian Savannah fragment interface. EntomoBrasilis, 8: 51-57. DOI: https://doi.org/10.12741/ebrasilis.v8i1.483

Marchiori, CH \& AM Penteado-Dias, 2008. Famílias de parasitóides coletadas em área de mata e pastagens no município de Itumbiara, Estado de Goiás. Acta Scientiarum. Animal Sciences, 24: 897-899. DOI: https://doi.org/10.4025/actascianimsci.v24i0.2340

Masson, MV, WS Tavares, FA Lopes, SA Souza, PJ Ferreira-Filho, LR Barbosa, C Wilcken \& JC Zanuncio, 2017. Selitrichodes neseri (Hymenoptera: Eulophidae) recovered from Leptocybe invasa (Hymenoptera: Eulophidae) galls after inicial release on Eucalyptus (Myrtaceae) in Brazil, and data on its biology. Florida Entomologist. 100: 589-593. DOI: https://doi.org/10.1653/024.100.0316

Melo, TL, MA Castellani, ML Nascimento, AO Menezes Junior, GF Pinto Ferreira \& OL Lemos, 2007. Comunidades de parasitoides de Leucoptera coffeella (Guérin-Mèneville \& Perrottet, 1842) (Lepidoptera: Lyonetiidae) em cafeeiros nas regiões Oeste e Sudoeste da Bahia. Ciência e Agrotecnologia, 31: 966-972. DOI: https://doi.org/10.1590/ S1413-70542007000400004

Noyes, JS, 2021. Universal Chalcidoidea Database. World Wide Web Electronic Publication. Available in: <http://www. nhm.ac.uk/chalcidoids>. [Access: 20.xii.2021].

O'Donnell, PP \& W Wright, 2021. Assessing the conservation and enhancement value of revegetated strips on arthropod assemblages in a pasture landscape. Journal of Environmental Management, 278: 11522. DOI: https://doi.org/10.1016/j.jenvman.2020.111522

Oliveira, ML, DRR Fernandes, TM Alvarenga, SR Andena, RO Araujo, CO Azevedo, DN Barbosa, PR Bartholomay, VA Costa, A DalMolin, IO Fernandes, SS Gadelha, F Gallardo, MG Hermes, CEL Justino, R Kawada, A Kohler, RIR Lara, DAA Lucena, A Macedo, C Margaría, BG Oliveira, DG Pádua, NW Perioto, TG Pikart, RB Querino, BB Rosa, BF Santos, EF Santos, K Schoeninger, DR Smith, A Somavilla, MT Tavares, FCV Zanella, K Zilch, EM Shimbori \& C Waichert, 2021. Hymenoptera in Catálogo Taxonômico da Fauna do Brasil. PNUD. Disponível em: <http://fauna.jbrj.gov.br/fauna/ faunadobrasil/96> [Access: 20.xi.2021].

Oliveira, RGMG, E Berti Filho, O Peres Filho \& FP Sales, 2014. Diversity of hymenopteran parasitoids (Hymenoptera: Chalcididae) associated with teak (Tectona grandis) forests. Advanced Science,1: 59-64. DOI: https://doi. 10.34062/afs. v1i2.1736

Ortega-Blanco, J, RC Mckellar \& MS Engel, 2014. Diverse Scelionid wasps in Early Cretaceous amber from Spain (Hymenoptera: Platygastroidea). Bulletin of Geosciences, 89: 553-571. DOI: https://10.3140/bull.geosci.1463

Palma-Santos, MC \& R Pérez-Maluf, 2010. Comunidade de parasitoides associada à cultura do café em Piatã, Chapada Diamantina, Bahia. Revista Ceres, 57:194-197

Parra, JRP \& A Coelho Junior, 2019. Applied Biological Control in Brazil: From Laboratory Assays to Field Application. Journal of Insect Science.19: 5: 1-6. DOI: https://doi.org/10.1093/jisesa/iey112

Perioto, NW, RIR Lara, A Selegatto \& ES Luciano, 2004. Himenópteros parasitoides (Insecta: Hymenoptera) coletados em cultura de café Coffea arabica L. (Rubiaceae) em Ribeirão Preto, SP, Brasil. Arquivos do Instituto Biológico, 71: 41-44

Quicke, DLJ, 2015. The Braconidae and Ichneumonidae Parasitoid Wasps: Biology, Systematic, Evolution and Ecology. Londres: Wiley-Blackwell.

Ronquist, F, 1995. Phylogeny and early evolution of the Cynipoidea (Hymenoptera). Systematic Entomologist, 20:309-335. DOI: https://doi.org/10.1111/j.1365-3113.1995.tb00099.x

Salas, C, 2019. Plants as Food for Adult Natural Enemies. pp. 35-47. In: Souza B., Vázquez L. \& Marucci R. (Eds) Natural Enemies of Insect Pests in Neotropical Agroecosystems. Springer, Cham. DOI: https://doi.org/10.1007/978-3-03024733-1_4

Santos Neto, AP, PAB Barreto, EF Gama-Rodrigues, AB Novaes \& A Paula, 2015. Produção de serapilheira 
em Floresta Estacional Semidecidual e em plantios de Pterogyne nitens Tul. e Eucalyptus urophylla ST Blake no sudoeste da Bahia. Ciência Florestal, 25: 633-643. DOI: https://doi.org/10.5902/1980509819614

Santos, PS \& R Pérez-Maluf, 2012. Diversidade de himenópteros parasitoides em áreas de mata de cipó e cafezais em Vitória da Conquista - BA. Magistra, 24: 84-90.

Scanavaca Junior, L \& JN Garcia, 2003. Potencial de melhoramento genético em Eucalyptus urophylla procedente da Ilha Flores. Scientia Florestalis, 64: 23-32.

Schoeninger, K, JLP Souza, C Krug \& ML Oliveira, 2019. Diversity of parasitoid wasps in conventional and organic guaraná (Paullinia cupana var. sorbilis) cultivation areas in the Brazilian Amazon. Acta Amazonica, 49: 283-293. DOI: https://doi.org/10.1590/1809-4392201804560

SEI - Superintendência dos Estudos Econômicos e Sociais da Bahia. 2021. Avaliable in: <http://www.sei.ba.gov.br/site/ resumos/notas/2902906_nota.pdf>. [Access: 2.ix.2021].

Silva, AB \& JM Brito, 2015. Controle biológico de insetospragas e suas perspectivas para o futuro. Agropecuária Técnica, 36: 248-258. DOI: https://doi.org/10.25066/ agrotec.v36i1.26306

Silva, AGA, 1964. Considerações sobre o combate químico associado ao biológico. Revista FIR, 7: 50-51.

Silva, JOS, MLE Costa, BS Paixão, JDB Macêdo, PMS Rodrigues \& EMF Lins-Neto, 2019. Natural Vs Managed Habitat: Effect Over the Seed-Predator Pachymerus nucleorum and Its Natural Enemies. Neotropical Entomology, 49:131-138. DOI: https://doi.org/10.1007/s13744-019-00727-z

Souza, NM, LR Junqueira, CF Wilcken, EP Soliman, MB Camargo, MA Nickele \& LR Barbosa, 2016. Ressurgência de uma antiga ameaça: Gorgulho-do-eucalipto Gonipterus platensis (Coleotera: Curculionidae). Circular Técnica ipef. n. 209. 1-20p. Available in:<http://ww.ipef.br/publicações/ ctecnica/>. [Access: 14.i.2021].

Talamas, EJ, NF Johnson \& M Buffington, 2015. Key to Neartic species of Trissolcus Ashmead (Hymenoptera, Scelionidae), natural enemies of native and invasive stink bugs (Hemiptera, Pentatomidae). Journal of Hymenoptera Research, 43: 45-110. DOI: https://doi.org/10.3897/ JHR.43.8560

Wilcken, CF \& E Berti Filho, 2008. Vespa-da-Galha do Eucalipto (Leptocybe invasa) (Hymenoptera: Eulophidae): Nova Praga de Florestas de Eucalipto no Brasil. IPEFInstituto de Pesquisa e Estudos Florestais. Programa de Proteção Florestal. Botucatu. Available in: <http://www. ipef.br/proteção/alerta-Leptocybe.invasa.pdf>. [Access: 05.iii.2021].

Zanuncio, JC, DLQ Santana, EC Nascimento, GP Santos, JB Alves, RC Sartório \& TV Zanuncio, 1993. Manual de pragas em florestas: biologia, ecologia e controle. Programa cooperativo de monitoramento de insetos em florestasIPEF- SIF. Editora Folha Florestal.

Zanuncio, JC, JB Torres, CAZ Sediyama, FF Pereira, PL Pastori, ED Wermelinger \& FS Ramalho, 2009. Mortality of the defoliator Euselasia eucerus (Lepidoptera: Riodinidae) by biotic factors in an Eucalyptus urophylla plantation in Minas Gerais State, Brazil. Anais da Academia Brasileira de Ciências. 81: 61-66. DOI: https://doi.org/10.1590/S000137652009000100008

$\star * \star * * * * * * *$
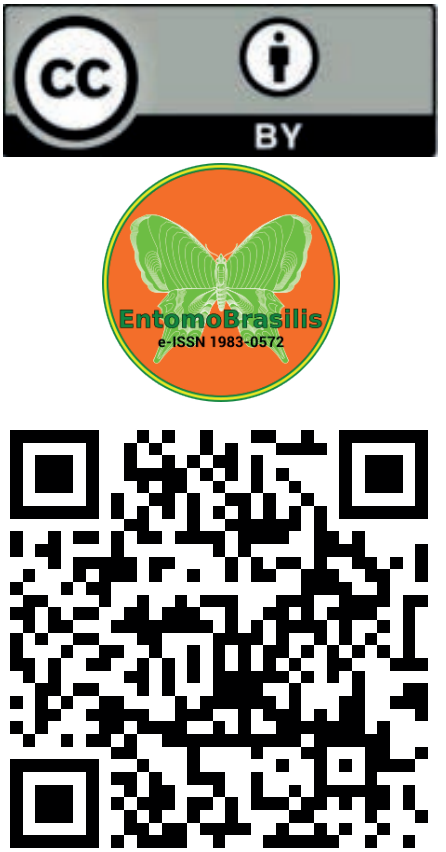